wave-lengths less than ten metres. On the whole, however, it was evident that the industry desires to remove from the minds of the public any tendency to delay the purchase of a new receiver on account of the inauguration of a television service in the future. It is unlikely, of course, that this service will in any way affect the use made of the ordinary set for the reception of sound programmes.

Another noteworthy and very recent development, shown for the first time at a radio exhibition, was a series of midget valves, about two inches or less in length and half-an-inch in diameter. These valves have now been placed on the market and are supplied in patterns of the triode, screen-grid and pentode types, with characteristics comparable with those of ordinary commercial valves. They are of very robust construction and are supplied with neat bases of either bakelite or steatite, the latter being specially suitable for the application of the valves to ultrashort wave working. Valve-holders are also available in either material. The production of these valves has given an impetus to the development of midget receivers, several types of which were displayed at the exhibition. One case is literally a pocket receiver, its dimensions being 6 in. $\times 4 \frac{1}{2}$ in. $\times 1 \frac{1}{8}$ in., and its weight $2 \mathrm{lb}$., complete with all batteries and frame aerial. This set is used with a single telephone receiver and is claimed to have a normal receiving range of 50-100 miles on the medium wave broadcasting band. It is known that such receivers have been in use by police forces for some time; but they have not hitherto been generally available to the public. Another receiver, employing four midget valves, weighs $9 \mathrm{lb}$., and its dimensions are about 9 in. square by 5 in. deep. This contains its own frame aerial, batteries and loud speaker, and since in size and appearance it is much like a box camera, it offers a new conception of the term 'portable wireless set'.

Readers of NATURE who are interested in obtaining further information on any items mentioned above or other matters covered by the Radio Exhibition will be assisted by reference to the Exhibition numbers of the Wireless World or World Radio (issues dated August 16 and 23 in each case).

\section{The State of Flowering known as Angiospermy}

$\mathrm{U}^{\mathrm{N}}$ NDER this title, Prof. J. McLean Thompson makes a very interesting contribution to current speculations as to the nature of the carpel (Publ. Hartley Bot. Laboratories, No. 12, University Press of Liverpool, 1934). His views are based mainly upon developmental studies and close com. parative studies of types within a limited range of affinity. These are sound grounds upon which to base morphological conceptions, and they require careful consideration, even if at first view they run directly counter to many popular conceptions.

The flower is regarded essentially as an axis of limited growth with a potentiality to produce sporogenous tissue. This growth centre earlier was vegetative, and the transition to sporogenous growth activity is indicated by the transitional region of bracteoles, sepals, etc.; similarly, the zone between two types of heterosporous tissue may be marked by carpellary structures bearing anthers; the essential fact is the tendency to bear sporogenous tissue upon an axial emergence which may take various forms.

A series of monocotyledonous forms with inferior ovaries is studied, with the result that no ground is found in their development for the view that the placentæ should be regarded as the ingrowths of the walls of sunken carpels. Rather there is extensive toral growth that gives an ovary wall; on the inner rim of this are outgrowths, of which nutrition is often defective and which may be interchangeably style or staminode.

In the same way, a study of the superior apocarpous gynæcium in the Ranunculaceæ suggests that the follicle is to be regarded as a toral upgrowth, after apical growth of the axis has ceased, which links together several associated primordia of a complex spiral phyllotaxis, primordia which lower on the axis would bear anthers and now are associated in the production of ovules. Similarly, the carpels of the Ranunculus flowers are the upper members of orthostichies which lower on the axis are represented by stamens; these upper members are essentially sporogenous, and in their central position bear ovules.

\section{Educational Topics and Events}

Dr. Nicholas Murkax Butuer's report for 1934 on the Carnegie Endowment for International Peace, Division of Intercourse and Education, is a very interesting record of extensive and carefully organised propaganda in the United States of America, in Europe, in Latin America and in the Orient. In the United States, the Endowment's doctrine of inter. national co-operation as the normal method of conducting world affairs in lieu of the rule of force finds ready acceptance in universities and in educa. tional circles generally: the difficulty is how to reach the people whose opinions have decisive weight when it comes to divisions in Congress and Senate. The 36 Senators who on January 29, 1935, voted against the ratification of the World Court Protocol, so that the affirmative majority fell short of the requisite two-thirds, prevented their Government, the report points out, from co-operating effectively in an important application of this doctrine-a heavy responsibility. International relations clubs, which are groups of students meeting regularly with. a faculty adviser, increased during the year in universities and colleges on the United States by 53, making a total of 523 . In addition, the movement extended to high schools, in which more than a hundred clubs have been established. The Endowment co-operates by presenting books and other material with the object of giving that background of facts which will enable students to read more understandingly the international news and exert a wider influence after leaving school and college. Outside the United States, 130 such clubs have been formed during the past four years in 29 countries, among which the only European countries are Bulgaria, Great Britain and Greece. Among publications for which the Endowment is responsible are "International Conciliation" and "L'esprit international". The work of the Division in Europe is conducted from Paris (173 Boulevard St. Germain) by a Directeur-Adjoint with the help of a committee representing Austria, Belgium, France (3), Germany (2), Great Britain (2), Greece, Hungary, Italy (2), Spain and Switzerland. 
SCIENCE versus superstition in China has not the news-value of the wars of the war-lords, but it is a conflict of which the issues are probably of far greater moment. A letter from Peiping Union Medical College published in School and Society of March 30 gives some idea of the strength of the defensive positions which bar the progress of Western science in that country. Every year a considerable number of natives of China graduate at universities in Europe and America and return to their native land with the object of entering upon the practice of medicine or engineering or whatever other profession they have been qualifying themselves for. Provided they are content to settle in one of the coastal cities, they have every prospect of establishing themselves in lucrative and honourable positions, in which they will have ample scope for demonstrating the value to the community of their newly acquired Western knowledge and training. But once they venture into the interior of China, they find themselves up against the most baffling obstacles. Their attempts to apply scientific methods are met with distrust, contempt and ridicule; a mass of deeply entrenched vested interests is stirred into activity ; they find their plans thwarted by intrigues and their young enthusiasm speedily evaporates. For in the majority of cases, such students get their first effective contact with Western ideology when they are already about sixteen years of age and consequently they suffer, on repatriation, from "a basic lack of confidence in the fundamental truth of that which they have learned abroad". There has been little or no common ground between the culture absorbed in childhood and the new culture, with its radically different modes of expression, picked up in the West. For the moment, the situation is not encouraging for those who have striven to provide a nucleus of foreign-trained Chinese with whose help China could learn to help herself.

\section{Science News a Century Ago}

\section{Memorial to Watt at Greenock}

The issue of The Times of August 24, 1835, reported : "The Committee appointed to conduct the erection of the Watt monument and public library at Greenock have with the approbation of the Provost and magistrates of Greenock, and the most worshipful the Provincial Grand Master for Renfrew. shire resolved that the foundation stone of the monument be laid with masonic honours on Tuesday, 25 th inst. The mason lodges, corporate bodies and trades desirous of doing honour to the memory of Watt, in his native town, have determined on a public procession and the necessary arrangements are being made."

\section{Fall of the Dent du Midi}

ON August 26, 1835, "A considerable portion of the principal peak of the Dent du Midi, one of the great spurs of Mont Blanc, fell with a tremendous crash into a deep and narrow valley situate about a league to the eastward of St. Maurice, on the road to Martigny. An accident of a similar nature occurred in the year 1818 when no less than 400 houses were washed away. In this recent instance the peak in its fall carried with it a glacier, which, filling up the valley, dammed up the stream which ran through it, until it had acquired sufficient force to drive before it the whole mass of earth and rocks into the bed of the Rhone, the course of which became so completely barred as to dry up all below it, and convert the upper part of its rugged and rocky course into a sort of temporary lake. . . . It was not known that any lives had been lost, but the passage across the Alps by the great Simplon road was for a time cut off. An attempt was immediately begun to reopen the communication by a temporary road, which was to describe a considerable circuit." ("Annual Register'.)

\section{The Yaguarundi}

"THrs beautiful species of felina, known only to naturalists by the description of it by Azara in his travels in South America," it is recorded in The Times of August 27, 1835, "has been brought for the first time to this country, and arrived last week in the Louisa Bailey from Guiana. It belonged to Mrs. Alboua, and has been presented by her to the Surrey Zoological Gardens. Its general form and character strongly resemble those of the puma, but having the limbs more slender in proportion to its size, the head more pointed, the strength of the jaws and teeth proportionately less, and the tail onethird of the animal's own length. ... It is an inhabitant of the deep recesses of the forests of Paraguay and Guiana, climbing trees readily, and preying upon monkeys and small birds, but will boldly attack large quadrupeds. Its possession will form a valuable addition to our knowledge of the history of this genus of animal."

\section{Halley's Comet seen in England}

Halley's Comet was first seen in England by Sir James South at Kensington, and then by the Rev. T. J. Hussey at Hayes Rectory. On August 31, 1835, The Times contained the following note: "Halley's Comet. Royal Observatory, Greenwich, Aug. 28. At $14 \mathrm{~h} .7 \mathrm{~m} .35 .6 \mathrm{~s}$. mean time, the right ascension of the comet was observed by the five feet equatorial to be $5 \mathrm{~h} .47 \mathrm{~m} .42 .1 \mathrm{~s}$. and declination 24 deg. $25 \mathrm{~m} .33 \mathrm{~s}$. north. It appeared very faint."

\section{The Steamships of Great Britain}

The Mechanics' Magazine of August 29, 1835, gave some interesting particulars of the number and size of the steam vessels in Great Britain, and the ports to which they belonged. The figures had been taken from a return recently made to Parliament. The total number of steam vessels registered in Great Britain was 397 with a total tonnage of 36,849 tons. There were 84 steam vessels not registered, and 46 under construction. Of the ports, London was at the head of the list with 98 vessels of 11,785 tons and Glasgow second with 56 vessels of 5,298 tons.

The six largest vessels at the time were: Monarch of London, 587 tons ; City of Aberdeen, 384 tons; Dundee of Dundee, 399 tons; City of Hamburgh, 380 tons; Perth of Dundee, 399 tons; John Bull of London, 398 tons. The registered tonnage, it was explained, was only about one third of the tonnage by admeasurement; and it was estimated that the aggregate tonnage of the steam vessels of Great Britain was about 100,000 tons. The sailing ship tonnage of Great Britain at this time was probably about $3,000,000$ tons. 